Egyptian Journal of Aquatic Biology \& Fisheries

Zoology Department, Faculty of Science,

Ain Shams University, Cairo, Egypt.

ISSN $1110-6131$

Vol. 23(2): 527- 544 (2019)

www.ejabf.journals.ekb.eg

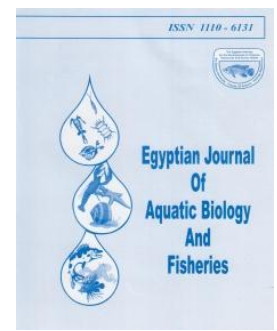

\title{
Effect of climate change on the reproduction pattern of sea urchin Echinometra mathaei at the Gulf of Suez, Red Sea, Egypt.
}

\author{
Mohamed Hamza Hasan \\ Aquatic Environment Department, Faculty of Fish Resources, Suez University, Suez, Egypt \\ Email: marinehamza@yahoo.com
}

ARTICLE INFO

Article History:

Received: March 13, 2019

Accepted: May 28, 2019

Online: June 2019

Keywords:

Echinometra mathaei

Reproduction

global warming

temperature

Gulf of Suez

\begin{abstract}
The reproduction patterns of E. mathaei's population at the Gulf of Suez were investigated during two periods, the first was 1992-1993 and the second was 2015-2016. The effects of elevating temperature during these periods on reproduction periodicities were studied. The surface water temperature showed an increase during the period $2015-2016$ by $1.36{ }^{\circ} \mathrm{C}$ at summer and $1.24{ }^{\circ} \mathrm{C}$ at winter from that recorded during 1992-1993. In 1992-1993, individuals of E. mathaei had one definite lengthy spawning season, which were expressed by main spawning period from June to August with maximum gonadal activity in July. On contrary, there was an obvious shift at the spawning season during 2015-2016; individuals of $E$. mathaei exhibit more than one breeding season. However, they are resting only during December, January, February, May and September. They showed four spawning seasons, the first from October to November, 2015, the second from March to April, 2016; the third from June to August, 2016, and the fourth from October to November, 2016. The overall sex ratio (males to females) during the first period (1992-1993) of the current study was 1:2.5, while in 2015-2016, it recorded an average male to female of 1:2.4. Size at sexual maturity decreased from 1992-1993 $(2.25 \mathrm{~cm}$ for females and $2.03 \mathrm{~cm}$ for males) to 2015-2016 (1. $8 \mathrm{~cm}$ for females and 1.5 $\mathrm{cm}$ for males). The study recorded a positive relationship between fecundity and size. The oocyte/female was highest in 1992-1993 (23 X $\left.10^{5}\right)$, decreased during 2015-2016 $\left(11.2 \times 10^{5}\right)$. Seasonal changes were observed in maturity stages related to spawning season at both periods of study. In the first period (1992-1993), most stages were represented with fluctuation in their percentage. The data collected showed that all stages showed one pattern of increasing and decreasing according to the stage until May, 1993 and subsequently, the pattern changed between the stages during the period from May to August. On the other hand, during the second period (2015-2016) all maturity stages were represented but in alternative states between the months of study.
\end{abstract}

\section{INTRODUCTION}

Most marine animals have seasonal reproductive cycles. However, environmental variables that synchronize reproduction of marine animals have been identified, and one of the most important environmental factors in this respect is temperature (Mercier and Hamel 2009). Temperature changes have been shown to synchronize reproduction in species that live in areas with seasonally changing sea temperature 
(Giese andPearse 1974). The seasonality changes in temperatures are mainly controlled by the characteristics of the geographical area.

The area concerned in this study is the Gulf of Suez, which is a long shallow and narrow body of water, $250 \mathrm{Km}$ long, $32 \mathrm{Km}$ wide and about 80-90 meter deep at its mouth, and averages only 20-30 meter depth along most of its length (Morcos, 1970 and Pearse, 1983). The prevailing north-westerly winds drive the surface waters south into the Red Sea (Morcos, 1970), and give the gulf a decidedly temperate character with seasonal temperature changes strongly influenced by the surrounding land. Due to of its northerly position and shallow depth, the Gulf of Suez is relatively temperate in character and large seasonal changes occur.

The increasing of surface water temperature at the gulf was evident during the successive years, it ranged from means of about $18{ }^{\circ} \mathrm{C}$ in winter to about $28^{\circ} \mathrm{C}$ in the summer (Pearse, 1969), while in 2000 the range of sea surface temperatures varied from $17.7^{\circ} \mathrm{c}$ in Winter to about $28.2^{\circ} \mathrm{c}$ in summer (Fahmy, 2003, ElShenawy et al, 2006), Also the range of temperatures increased in 2015 varied from means of 17.96 ${ }^{\circ} \mathrm{c}$ in winter to about $29.25^{\circ} \mathrm{C}$ in Summer (Abdelmongy and El-Mouselhy, 2015). As water temperature depends upon various factors, including radiation income, surface exchange with air temperature, beach radiation, latent heat and evaporation (Tailing, 1976), the increase in sun radiations and flux received from the sun during these years caused the surface water temperature to be increased. The increase in earth's temperature which called global warming refers to the recent and ongoing rise in global average temperature near Earth's surface. It is caused mostly by increasing concentrations of greenhouse gases in the atmosphere. The greenhouse effect is commonly a process of heat being let in and then being unable to escape.

The fauna of the Gulf of Suez consist almost entirely of members of the tropical Indo-Pacific assemblage, and many of species range across the Indian Ocean in the tropical central pacific (Por, 1978). Because of such genetic continuity, and the shallow temperate character of the Gulf of Suez, populations of tropical species with the Gulf may be near the extremes of their ecological and physiological capabilities (Pearse, 1983).

Echinometra mathaei is distributed widely on most coral reefs and are often the most prevalent sea urchin species on the reefs they inhabit (McCartney et al. 2000; McClanahan and Muthiga 2001). Sea temperatures seem to be important in regulating the reproduction periodicities also has a great effect on fertilization and early development stages of the sea urchin (Cohen-Rengifo et al, 2013). The reproductive cycle of $E$. mathaei has been examined over many areas of the world (Pearse 1968, 1969a; Pearse and Phillips 1968; Fujisawa and Shigei 1990; Drummond 1995; Alsaffar and Lone 2000; Muthiga and Jaccarini 2005). These studies showed different modes of reproduction, at some areas reproducing continuously throughout the year (Pearse and Phillips 1968; Kelso 1971), while others showed restricted spawning periodicities (Fujisawa and Shigei 1990; Arakaki and Uehara 1991; Muthiga and Jaccarini 2005).

Yonge (1940) believed that the spawning periods of many of the species at the Low Isles, Great Barrier Reef, were influenced by the temperature fluctuations. The same author divided the spawning periods of tropical species into four groups in relation to inferred temperature requirements: those spawning (1) at about $30^{\circ} \mathrm{C}$, (2) between $23^{\circ} \mathrm{C}$ and $28^{\circ} \mathrm{C}$ and having semiannual spawning period in some areas, (3) at anything above about $24^{\circ} \mathrm{C}$, and (4) at anything above $18^{\circ} \mathrm{C}$. A lower "critical temperature around $18-20^{\circ} \mathrm{C}$, corresponding to Yonge's fourth category, may be involved with the reproduction of Echinometra mathaei. Murintsev (1963) further 
shows that surface sea temperatures in the West-central Pacific generally don't fall below $18-20{ }^{\circ} \mathrm{C}$ except in Japan, and Japan is the only area in this region where Echinometra mathaei seems to have a distinct summer spawning period.

The breeding patterns of tropical sea urchins have studied by many investigators. Although a number of species seem to reproduce throughout the year, many species have periodic seasonal breeding pattern. These patterns include both semi-annual breeding rhythms, as well as monthly rhythms. Pearse and Barksdale (1986) reported that most species of invertebrates in the northern subtropical parts of the region (e.g. Red Sea) tend to spawn in boreal summer, while those in southern subtropical parts (e.g. Southern Great Barrier Reef) tend to spawn in austral summer.

Pearse (1969) mentioned that the sea urchin Echinometra mathaei spawns in summer in the Gulf of Suez and Japan, but continuously spawns throughout the year elsewhere in its distribution including off Southern Australia, where sea temperatures more than $30{ }^{\circ} \mathrm{C}$.

The Indo-Pacific echinoid Echinometra mathaei reproduce continuously throughout the year in the northern Red Sea and most other areas, (Pearse, 1968; Pearse 1969; Pearse and Phillips, 1968). However, in Gulf of Suez and off Japan, gametogenesis is fully synchronous among individuals of this species, and spawning is restricted to summer months.

Therefore, during the current work we investigate the reproduction pattern in E. mathae $i$ with the aim of assessing the reproductive periodicity and evaluating the relationship between its reproductive cycle and sea water temperature at Gulf of Suez, Red Sea.

\section{MATERIALS AND METHODS}

\section{Study site:}

The Gulf of Suez is a part from the Red Sea, the gulf has temperate characters since the extensive sandy bottom, and relatively shallow depths compared to the adjacent Red sea and Gulf of Aqaba. The length of the gulf is $314 \mathrm{Km}$ and it varies in width from 19 to $32 \mathrm{Km}$ and average depth $40 \mathrm{~m}$ with a max. depth of $70 \mathrm{~m}$.

Ain Sukhna area in the western Gulf of Suez $60 \mathrm{Km}$ south Suez city (Fig., 1). The Site is well protected and has weak water currents and low wave action. The area of study is shown in Figure 1. The area of study is characterized by scattered coral patches and rocky and sandy substrate.

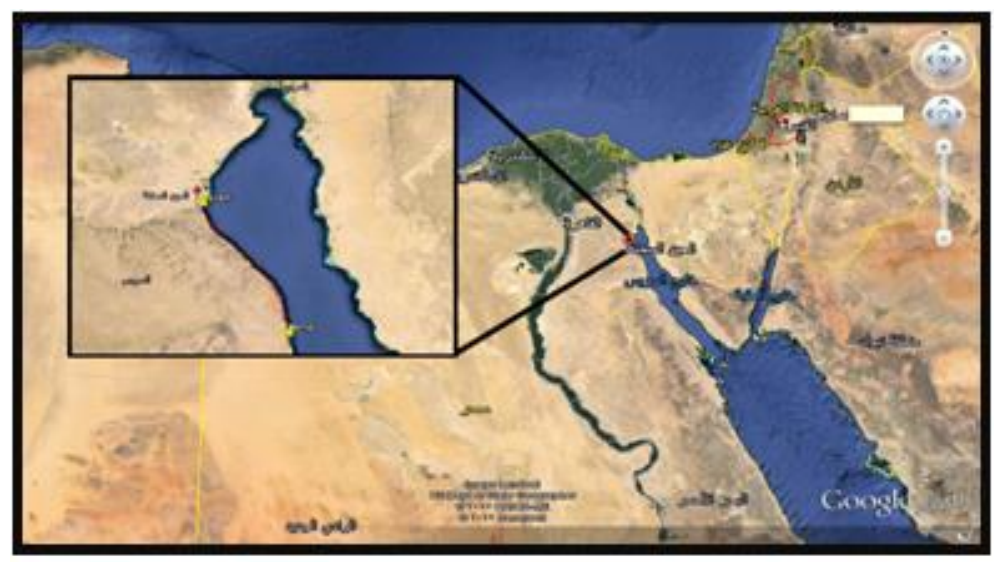

Fig. 1: The study area at the north-western Gulf of Suez 


\section{Field Observations and Specimen collection:}

A survey was made at the study area during two periods, the first from October, 1992 to November, 1993 and the second from October 2015 to November 2016. During each visit, water and air temperatures were recorded using a graduated thermometer. Twenty five specimens were collected monthly from both intertidal and subtidal areas. Intertidal specimens were collected by hand, and SCUBA diving was used to collect the subtidal specimens. The individuals were selected from among the largest ones found to avoid any bias arising from the relation between size and the gonad index value. Small and medium size specimens were also sampled to determine the population's size at first sexual maturity.

\section{Reproduction studies:}

Specimens were dissected upon arrival at the laboratory after $1 \mathrm{~h}$ journey (during this journey the animals were kept in aerated water tanks). Coelomic fluid was drained from all tissues and sediments were removed from the gut. Drained weight was measured to the nearest $10^{-2} \mathrm{~g}$, then the gonads were weighted to the nearest $10^{-3} \mathrm{~g}$. The gonad index (GSI) was calculated as follows:

\section{GSI $=\frac{\text { Wet weight of gonad }}{\text { Wet weight of urchin }} \times 100$}

The gonads were examined microscopically to determine the sex of each individual, then the percentage of males and females were calculated each month for sex ratio determination.

The size at first maturity was determined by examining the gonad of each individual urchin.

An estimate of absolute fecundity (FA) was made from a small sample of the ovary (weighted to the nearest $10^{-4} \mathrm{~g}, \mathrm{GW}$ ). Oocytes used for this calculation were collected from large ovary tubules. Eggs were carefully removed from the ovary, placed in filtered seawater and shaken to suspend them evenly in $5 \mathrm{ml}$ saline solution $(0.9 \mathrm{NaCl})$. This suspension was then poured into a petri dish marked with a $25-\mathrm{cm}$ grid. The mean number of eggs per grid was calculated from a six randomly selected grids and was multiplied by the number of grids within the petri dish. The absolute fecundity was determined by dividing the gonad weight by the sample weight and multiplying this by the mean number of oocytes in the sample.

For each urchin the average number of oocytes in the entire gonad was calculated by applying the following formula

Total oocyte number $=\frac{\text { Egg number of sample } \times \text { total gonad weight }}{\text { weight of sample }}$

The gonads were examined externally and microscopically to define the maturity stages. In total, five maturity stages were defined in both males and females based on morphology size and appearance of the gonads.

\section{RESULTS}

\section{Temperature}

The temperature measured at 2015-2016 recorded a mean value of $29.56{ }^{\circ} \mathrm{C}$ during summer season and $18.76^{\circ} \mathrm{C}$ during winter season. These values showed an increase in temperature by $1.36{ }^{\circ} \mathrm{C}$ at summer and $1.24^{\circ} \mathrm{C}$ at winter from the values 
recorded at $1992-1993$ that was $28.20{ }^{\circ} \mathrm{C}$ during summer season and $17.5{ }^{\circ} \mathrm{C}$ during winter season (Table, 1).

Table 1: Mean water temperature recorded at different years at the study site.

\begin{tabular}{ccc}
\hline Years & \multicolumn{2}{c}{ Temperature $\left({ }^{\circ} \mathrm{C}\right)$} \\
& Summer & winter \\
\hline $1992-1993$ & 28.20 & 17.5 \\
$2015-2016$ & 29.56 & 18.74 \\
\hline
\end{tabular}

\section{Sex ratio}

The sex ratio of Echinometra mathaei recorded differences between the two periods of study. In 1992-1993, it recorded an average male to female of 1:2.5 with a percentage of $20 \%$ males and $80 \%$ females. The highest percentage recorded at that period was $11.7 \%$ males to $88.3 \%$ females at March, 1993 and the lowest sex ratio was recorded at November, 1993 with a percentage of $30 \%$ males and $70 \%$ females (Fig. 2). While in 2015-2016, it recorded an average male to female of 1:2.4 with percentage $35.2 \%$ males and $64.8 \%$ females. The highest percentage recorded $29.1 \%$ males and $70.9 \%$ females at October, 2015 and the lowest percentage recorded 40.3\% males and 59.7\% females at January 2016 (Fig. 3). The sex ratio was significantly deviated from the expected ratio $1: 1$ at the two periods, but the deviation was more in 1992-1993 than in 2015-2016. However, the ratio is not constant throughout the period of study particularly during the spawning season.

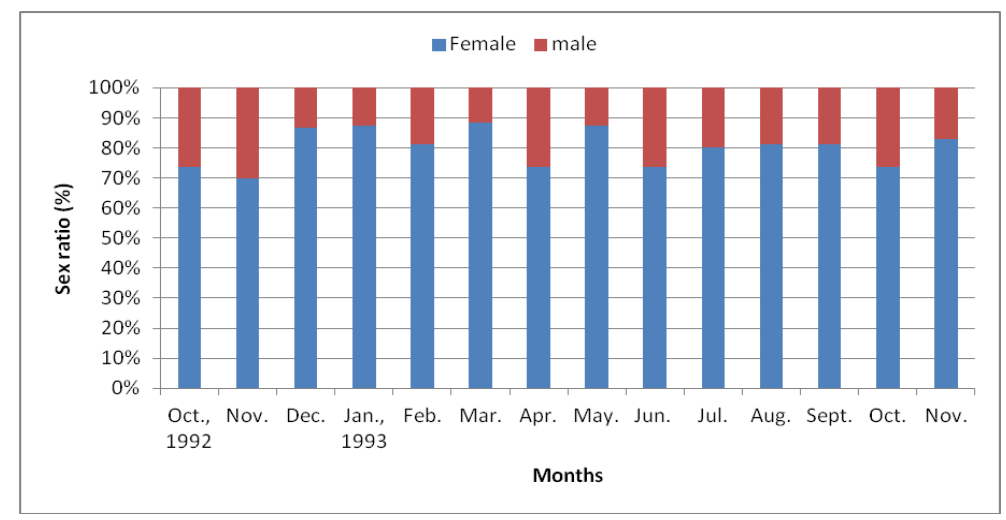

Fig. 2: Monthly variations in sex ratio of E. mathaei during the period from Oct., 1992 to Nov., 1993.

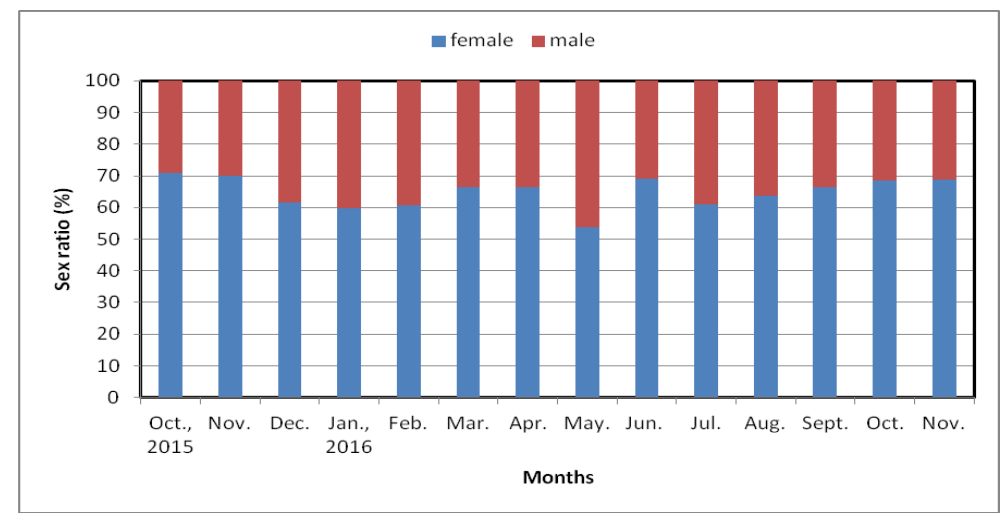

Fig. 3: Monthly variations in sex ratio of E. mathaei during the period from Oct., 2015 to Nov., 2016. 
Generally, females markedly outnumbered males all the year around particularly during summer and autumn months at the first period (1992-1993), while at the second period (2015-2016), the number of females still outnumbered males throughout the year but with less deviation from the 1:1 ratio. On the other hand, during the breeding season, the number of females exceeds the number of males.

\section{Size at sexual maturity}

During the period from October, 1992 till November, 1993, the males of $E$. mathaei reached their sexual maturity at $2.03 \mathrm{~cm}$ test diameter, while females reached its sexual maturity at $2.25 \mathrm{~cm}$ test diameter. Whereas, E. mathaei individuals reached their sexual maturity at smaller sized during the period from October, 2015 to November, 2016, the males reached their sexual maturity at $1.5 \mathrm{~cm}$, while females reached the sexual maturity at $1.8 \mathrm{~cm}$ (Table, 2).

Table 2. Size at first sexual maturity of E. mathaei recorded at the two periods of study.

\begin{tabular}{lcccc}
\hline \multirow{2}{*}{ Months } & \multicolumn{2}{c}{$1992-1993$} & \multicolumn{2}{c}{ 2015-2016 } \\
\cline { 2 - 5 } & female & male & female & male \\
\hline Oct. & 2.25 & 2.05 & 1.83 & 1.5 \\
Nov. & 2.19 & 2.06 & 1.8 & 1.52 \\
Dec. & 2.15 & 2.03 & 1.79 & 1.53 \\
Jan. & 2.36 & 2.03 & 1.8 & 1.5 \\
Feb. & 2.3 & 2.04 & 1.78 & 1.52 \\
Mar. & 2.3 & 2.01 & 1.8 & 1.52 \\
Apr. & 2.25 & 2.03 & 1.8 & 1.49 \\
May. & 2.2 & 2.06 & 1.86 & 1.48 \\
Jun. & 2.2 & 2.06 & 1.86 & 1.46 \\
Jul. & 2.15 & 2.07 & 1.81 & 1.45 \\
Aug. & 2.1 & 2.1 & 1.77 & 1.46 \\
Sept. & 2.25 & 2.11 & 1.79 & 1.5 \\
Oct. & 2.25 & 2.05 & 1.81 & 1.51 \\
Nov. & 2.2 & 2.07 & 1.81 & 1.52 \\
\hline
\end{tabular}

\section{Reproductive seasonally and Gonad Index}

The reproductive cycle of E. mathaei at Gulf of Suez was investigated for the same two periods (1992-1993 and 2015-2016). Gonad index values showed high variation during the two periods. In the period 1992-1993, individuals of E. mathaei had one definite lengthy spawning season, which were expressed by main spawning period from June to August with maximum gonadal activity in July. For females the average G.S.I. decreased from October, 1992 to March, 1993. Then it began to increase from April to May. In June the average G.S.I. sharply increased to reach its peak (12.5) at July and then decreased from September to November, 1993. Males exhibited a similar pattern as in females, however, maximum G.S.I. value was recorded at July (5.2).

On contrary, there was an obvious shift at the spawning season during 20152016, from that recorded in 1992-1993. At the period 2015-2016, individuals of Echinometra mathaei didn't exhibit a specific breeding season. It seems that they are not synchronized in their reproductive activities and they have more than one spawning season. However, they are resting only during December, January, February, May and September. Reproductive efforts of females and males are maximal in summer and moderate in winter and spring. Individuals exhibit a wide range in their G.S.I. with maximal values recorded in July and August. They showed four spawning seasons, the first from October to November, 2015, the second from March to April, 2016 the third from June to August, 2016, and the fourth from October to November, 2016. For females the average G.S.I. recorded high value 
during October and November, 2015 being 5.98 and 5.12, respectively. Then the G.S.I. value decreased from December (3.01) to February (2.96). Afterwards, it increased again at March (5.21) and April (5.88), before it drops during May (2.16) and increased once more from June (5.98) to August (5.66), with a peak at July (6.18). In September, 2016 the average G.S.I. sharply decreased to reach 3.34 then increased again at October and November, 2016, being 5.29 and 4.89, respectively. The male gonads exhibited exactly the same pattern as observed for females (Figs. 4 \& 5).

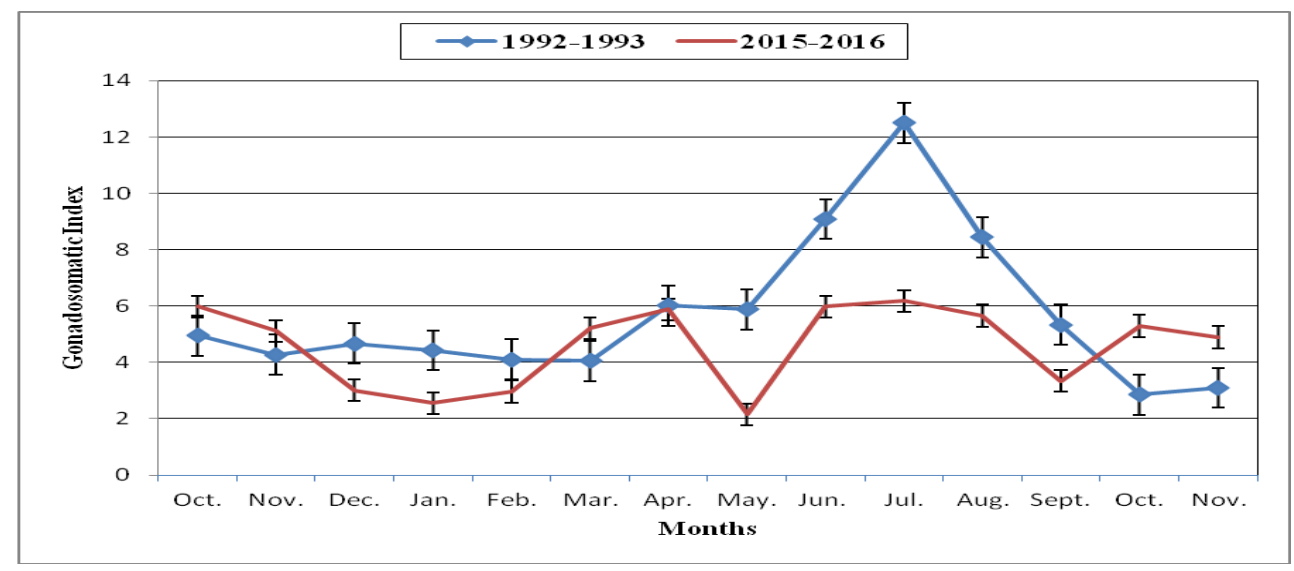

Fig. 4: Monthly fluctuation in gonadosomatic index for females Echinometra mathaei with standard deviation (SD) during the two periods 1992-1993 and 2015-2016.

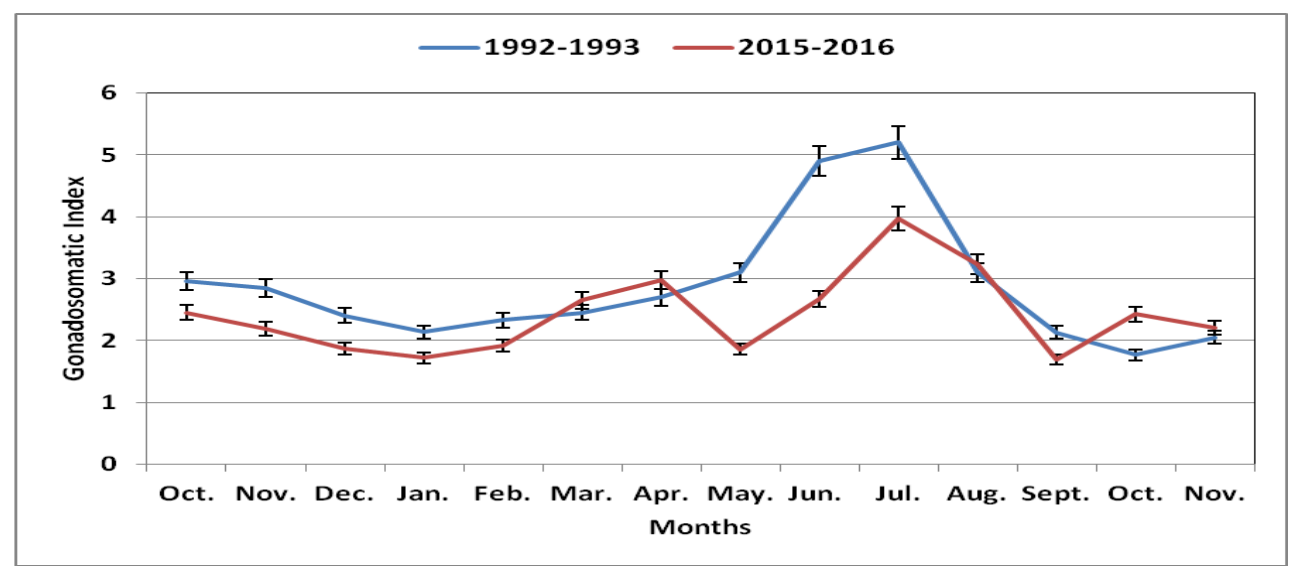

Fig. 5: Monthly fluctuation in gonadosomatic index for males Echinometra mathaei with standard deviation (SD) during the two periods 1992-1993 and 2015-2016.

\section{Fecundity}

Fecundity (number of mature oocyte/female) of E. mathaei showed high variation during the two periods of study. The data obtained showed that fecundity was highest in 1992-1993 period ranged between $0.9 \times 10^{5}$ and $61 \times 10^{5}$ oocyte/female, while it decreased during the period 2015-2016 ranged from 0.4 X $10^{5}$ and $41.7 \times 10^{5}$ oocyte/female.

The relationship between E. mathaei's size and fecundity was investigated during this study. At the first period (1992-1993), the largest female recorded was $7.5 \mathrm{~cm}$ test diameter and its fecundity was $23 \times 10^{5}$ oocyte, while the smallest female recorded was $2.5 \mathrm{~cm}$ test diameter and its maximum fecundity was $0.9 \times 10^{5}$ oocyte. There was a highly significant difference between the size of E. mathaei and fecundity $(\mathrm{p}=0.006)$. Whereas during the second period $(2015-2016)$ the largest female recorded was $7.5 \mathrm{~cm}$ test diameter and its fecundity was $11.2 \times 10^{5}$ oocyte, 
while the smallest female recorded was $2.0 \mathrm{~cm}$ test diameter and its maximum fecundity recorded $0.4 \times 10^{5}$ oocyte. Also there was a high significant difference between fecundity and different years investigated $(p=0.002)$ (Fig. 6).

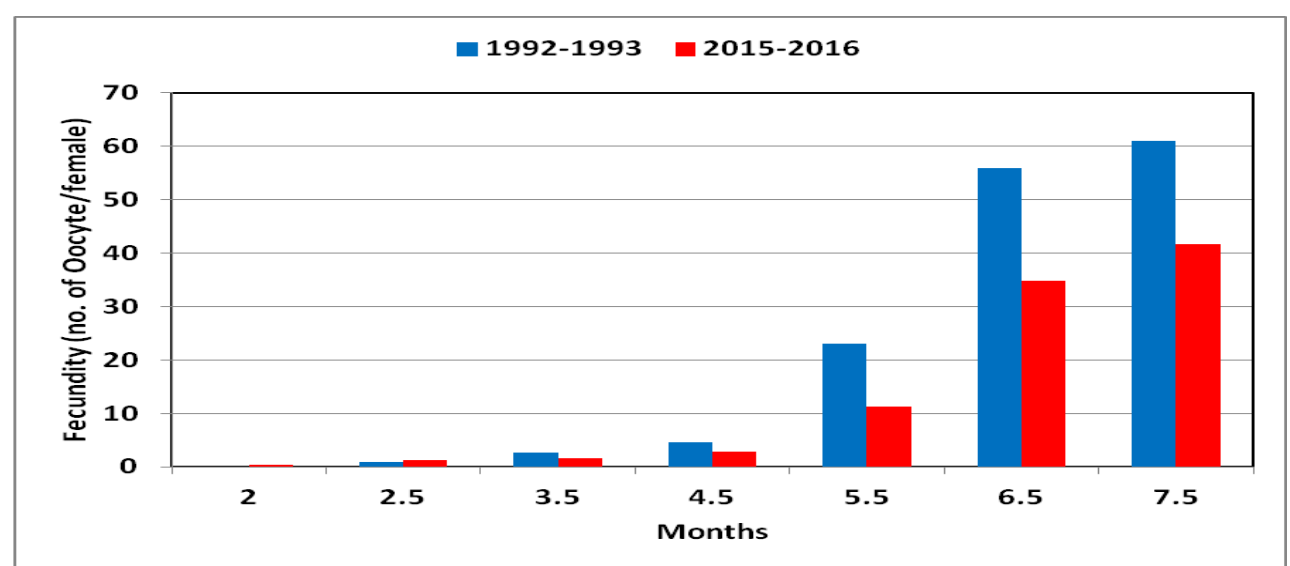

Fig. 6: Variation in fecundity (no. X $10^{5}$ ) of Echinometra mathaei with length during the two periods of study (1992-1993 and 2015-2016).

\section{Gonad morphology and maturity stages}

The gonads of both sexes of $E$. mathaei are five broad ribbons, located just beneath the test and extended along the five interambulacral columns. They are pointed interiorly, slightly rounded posteriorly and the broadest part at the middle of the ribbon. On the outer side of the ribbon there is a groove which runs along the ribbon from the posterior part to the interior one. The groove is terminated by a small gonoduct, which open in the genital pore at the apical system. Mature oocytes are stored in the lumen of acini till the spawning period. The large oocytes are found at the center of the lumen, whereas the small ones are found near the periphery of the acini.

In total, five maturity stages were defined based on morphology size and appearance of the gonads. In immature stage (Stage I), gonad growth involved the formation of new ribbon arising from the gonad base, with a subsequent increase in ribbon length and diameter, the gonads are very small, thread like in shape with whitish color and extended from apical system to about half of the interambulacral columns. At stage II (growing stage), both females and males could be identified by the presence of developing oocytes and spermatocytes. At maturity stage (Stage III), and as the gonads approached maturity the gonads are large and consist of large number of acini which cann't be distinguished by the naked eye. Microscopic examination revealed that acini are thread like and elongated in males but short and thick in females. The color of the gonads varied from pale yellowish to dark orange in ripe females and varied from creamy color to dark brown in mature males. These colors were related at least partly to the sex and state of maturity of the animals. At partially spawned stage, which occur throughout the spawning season, the simultaneous presence of both spawned and unspawned tubules indicated that partial spawning was occurring (stage IV), which could be a characteristic of this species. Spent gonad tubules (stage V) were wrinkled and greatly reduced in size, with white translucent color for both species.

In this respect, seasonal changes were observed in maturity stages related to spawning season at both periods of study. In the first period (1992-1993), most stages were represented with fluctuation in their percentage. The partial spawned stage fluctuated between 5 to $12 \%$ from October to April, it rises to $47 \%$ to $80 \%$ 
during May to August (the spawning season), then decreased again to $25 \%$ to only 4\% from September to November. Growing stage increased from 53\% at October, 1992 to reach its maximum percentage being 38\% at March, 1993, before it decrease beginning from April (28\%) to August (2\%). The mature stage exhibited the same pattern, increased from 10\% at October, 1992 to 56\% at April, 1993, then decreased from May, 1993 (25\%) to August, 1993 (8\%), indicate a definite spawning season from May to August. It is obvious that there was a reverse relationship between partially spawning stage and both growing and mature stages at which the former increased when the latter two stages decreased. The data collected showed that all stages had one pattern of increasing and decreasing according to the stage until May, 1993 and subsequently, the pattern changed between the stages during the period from May to August (Fig. 7).

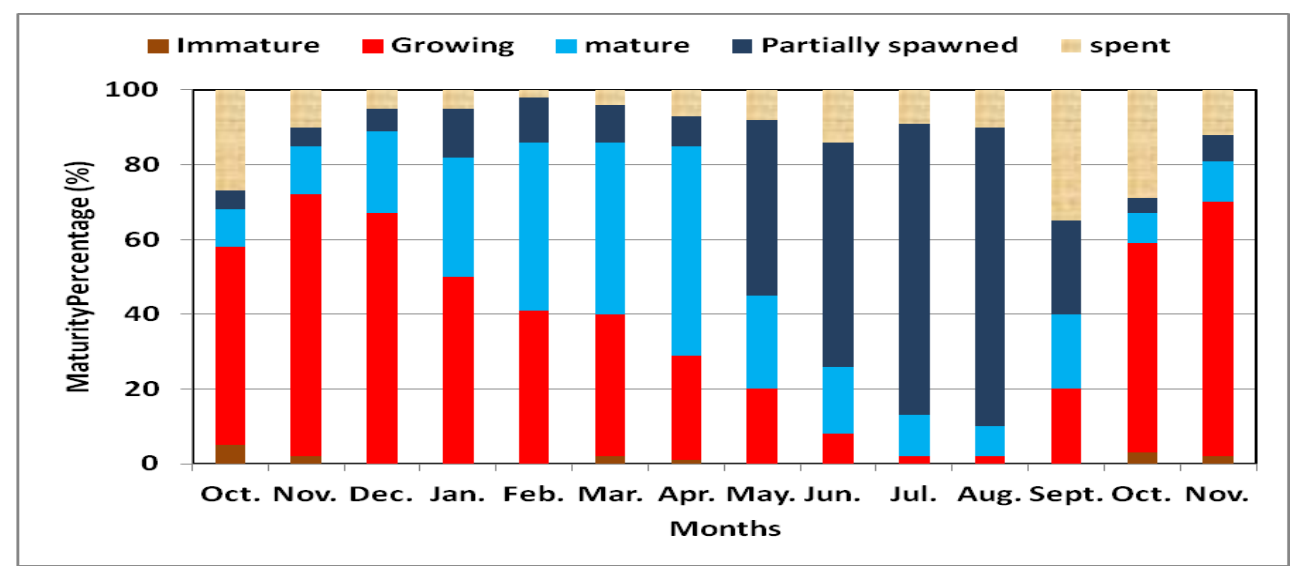

Fig. 7: Frequency of gonadal development of female Echinometra mathaei from October, 1992 to November, 1993 (no.=280).

On the other hand, during the second period (2015-2016) all maturity stages were represented but in alternative state. The growing stage increased from $20 \%$ at October, 2015 to $69 \%$ at December, 2015, then decreased to only 8\% at April, 2016, increased again to $37 \%$ at May, 2016, followed by a reduction to $12 \%, 4 \%$ and $8 \%$ during June, July and August, 2016, respectively. An increase was recorded during September, 2016 before it decreased again during October and November, 2016. Whereas mature and partially spent individuals showed an opposite patterns, they showed high percentages during October, 2015 followed by a decrease during November, 2015, with the appearance of high percentage of spent individuals (45\%). While mature individuals increased during January and February, 2016, recorded $48 \%$ and $58 \%$, respectively, the partially spent individuals recorded low percentages fluctuated between $1 \%$ and $6 \%$ during the same months. Beginning from May, 2016 the mature individuals deceased (37\%), while the partially spent individuals increased (22\%). This situation continued during March and April, 2016, then at May, 2016 the situation reversed again as the percentage of mature individuals recorded $48 \%$ and the percentage of partially spawned and spent individuals recorded 6 and 4\%, respectively. Again during June, July and August, 2016, the mature individuals decreased recorded 40,39 and 29\%, respectively, while the partially spawned individuals increased, recorded 30, and 35\%, before it decreased again during August and September, 2016 recording only 8\%. The spent individuals showed increasing percentages from June to August, 2016, recorded 16, 21 and 54\%, while there was no record of spent individuals during September, 2016. At October 
and November, 2016, the mature individuals decreased to 34 and 22\%, respectively, while both partially spent and spent individuals increased (Fig. 8).

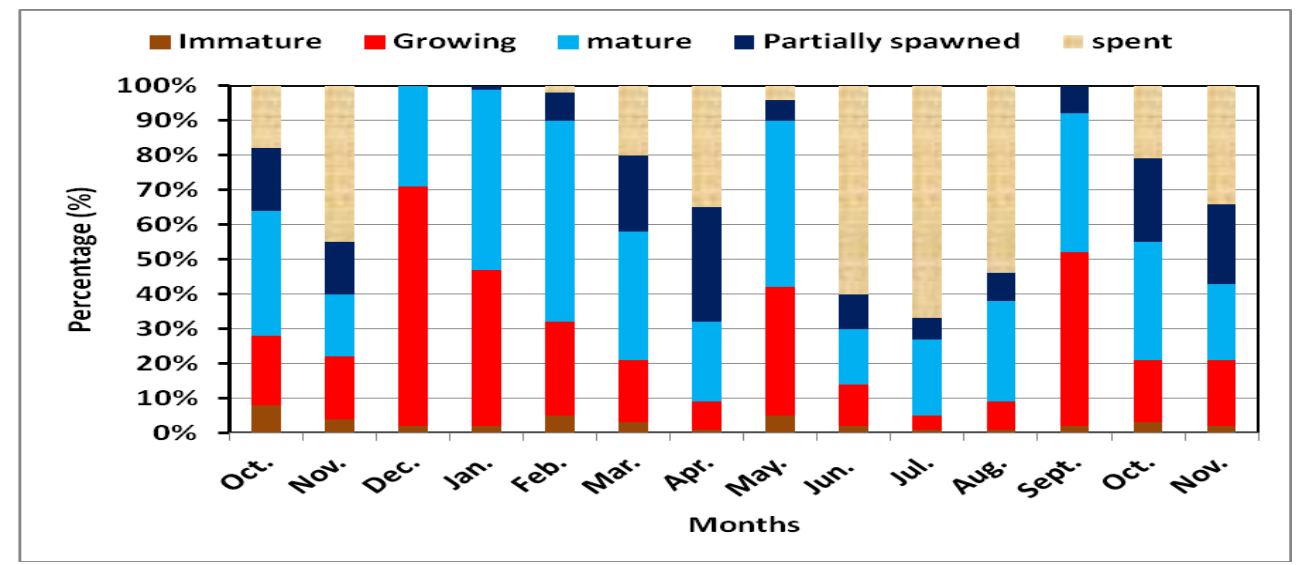

Fig. 8: Frequency of gonadal development of female Echinometra mathaei from October, 2015 to November, 2016 (no. $=280$ ).

\section{DISCUSSION}

Most marine invertebrates undergo an annual reproductive cycle. Many show variations of timing in the events of the cycle from place to place and from year to year (Hasan, 1995; Abou zied, 1991).

The general seasonal nature of these cycles as well as sequential changes associated with a well-defined cycle clearly indicates that there must be mechanisms of synchronization not only within population but also with other activities in the organisms (Pearse and Barksdale, 1986). Operation of the reproduction involve a cyclic demand for energy and material. This fueling of reproduction show a temporal pattern in amplitude, frequency and direction, with the overall reproductive strategy (Fauda, 1990). The energy demand is due to the food reserve and the quantity of energy and materials devoted to reproduction compared to other metabolic needs, this is one of the factors controlling the reproduction events, in addition to developmental phasing which include the time of onset and size at sexual maturation, while the external factors include lunar rhythm, salinity and the most important of all temperature. Not only an external factor, temperature affect all the internal process, beginning from gamete maturation, sexual maturity, reproductive efforts..etc. Water temperature depends upon various factors, including radiation income, surface exchange with air temperature, beach radiation, latent heat and evaporation (Tailing, 1976).

Since the mid- $20^{\text {th }}$ century the human activity gradually increased and became the dominant cause of observed warming in earth's climate, which increased during the last three decades than any preceding decade since 1850 (IPCC, 2013). Due to the last 15-year periods there was a trend of continuous elevating temperature starting in 1995,1996 , and 1997 being $0.13{ }^{\circ} \mathrm{C}, 0.14{ }^{\circ} \mathrm{C}$ and, 0.07 [ -0.02 to 0.18$]{ }^{\circ} \mathrm{C}$, respectively (Stocker et al. 2013). Many literatures recorded an increase in earth's temperature of most regions since the early 1980s, observed warming ranged between $3^{\circ} \mathrm{C}$ and $2^{\circ} \mathrm{C}$ during the period from 1971 to 2010 (Held et al., 2010; Xie and Vallis, 2012; Koven et al., 2013). In this warming trend, the Northern Hemisphere, showed its warmest 30-years period from 1983 to 2012 of the last 1400 years. The increase in water temperature due to warming is different according to depth, where the upper ocean layer $(0-700 \mathrm{~m}$ depth) warmed more than deeper 
depths because more than $60 \%$ of the net energy increase in the climate system is stored in the upper ocean $(0-700 \mathrm{~m})$ and only about $30 \%$ is stored in the ocean below $700 \mathrm{~m}$ (Knutti et al., 2008). On a global scale, the ocean warming is largest near the surface, and the upper $75 \mathrm{~m}$ warmed by 0.11 [0.09 to 0.13$]{ }^{\circ} \mathrm{C}$ per decade over the period 1971 to 2010 . While during the period from 2003 to 2010 the temperature increased more slowly than the period from 1993 to 2002 (Knutti, and Hegerl, 2008, IPCC, 2013).

Temperature change is not regionally uniform, the strongest ocean warming is projected for the surface in tropical and Northern Hemisphere subtropical regions, which ranged between $0.6^{\circ} \mathrm{C}$ to $2.0^{\circ} \mathrm{C}$ per decade (Knutti and Tomassini 2008). The temperature data acquired from the current study is compatible with the conclusion that the tropical and subtropical area recorded strongest ocean warming, it recorded an increase in water temperature at the Gulf of Suez of $1.63{ }^{\circ} \mathrm{C}$ during summer and $1.24{ }^{\circ} \mathrm{C}$ per 23 years period from 1992-1993 to 2015-2016.

Temperatures recorded during the current study for the second period (20152016) were in agreement with results of previous records at the Red Sea as Abdelmongy and El-Moselhy (2015), who recorded a summer temperature of 29.25 ${ }^{\circ} \mathrm{C}$ and a winter temperature of $17.96{ }^{\circ} \mathrm{C}, 28.2{ }^{\circ} \mathrm{C}$ at summer and 20.17 at winter (Madkour, 2013) and $30.5{ }^{\circ} \mathrm{C}$ at summer and $22.8{ }^{\circ} \mathrm{C}$ at winter (Dorgham et al., 2012).

Sea temperatures seem to be important in regulating the reproduction periodicities also has a great effect on fertilization and early development stages of the sea urchin, (Cohen-Rengifo et, al 2013).

Maria Byrne, et al. (2009) mentioned that global warming is causing ocean warming and acidification. The interactive effects of warming and acidification on fertilization and development of this echinoid were determined. Experimental treatments $\left(20-26^{\circ} \mathrm{C}\right.$, pH 7.6-8.2) were tested in all combinations for the 'businessas-usual' scenario, with $20^{\circ} \mathrm{C} / \mathrm{pH} 8.2$ being ambient. Percentage of fertilization was high $(>89 \%)$ across all treatments. There was no difference in percentage of normal development in any $\mathrm{pH}$ treatment. In elevated temperature conditions, $+4^{\circ} \mathrm{C}$ reduced cleavage by 40 per cent and $+6^{\circ} \mathrm{C}$ by a further 20 per cent. Normal gastrulation fell below 4 per cent at $+6^{\circ} \mathrm{C}$. At $26^{\circ} \mathrm{C}$, development was impaired. Providing that temperature, but not $\mathrm{pH}$, compromises sea urchin fertilization and early development under near-future climate change scenarios.

The current study showed that the increased water temperature at the study site seems to affect the reproduction rhythm which recorded a great difference between the two periods of study (1992-1993 and 2015-2016). The reproductive cycle showed positive correlation with the rise of surface water temperature. The important role of temperature variations in the reproduction of E. mathae $i$ was shown by many other workers from other parts of the world (e.g., Pearse 1969a; Sakairi et al. 1989; Byrne 1990; Pecorino et al. 2014; Wangensteen et al. 2013). Variation in temperature suggested being the key exogenous signal for spawning in E. mathaei (Bronstein and Loya, 2014).

According to many authors temperature play the major role governing the reproduction of echinoids. Du to this concept Pearse (1974) suggested that $E$. mathaei might have a restricted spawning period in the higher latitudes (above $27^{\circ}$ $\mathrm{N}$ ), which its spawning is expected to be restricted to the summer months, and continuous spawning throughout the year closer to the equator where the environmental factors, especially temperature, are presumed more stable. This proposal was consonant with many studies from many parts of the world as the 
continuous reproduction recorded from Honsu, Japan (Kobayashi, 1969), Minatogawa, Japan (Fujisawa and Shigei, 1990 ), Hawaii (Kelso, 1971). On the other hand, many reports from higher latitudes recorded restricted spawning period related to the seasons with higher temperature with an annual peak during AugustSeptember and was followed by a drop in the GSI value in October, indicating a single annual spawning event as recorded from Kenya (Muthiga and Jaccarini, 2005), Persian Gulf (Keshavarz, 2017), Tanzia (Bronstein and Loya, 2014), Eastern coast of South Africa (Drummond, 1995). While previous studies at the Gulf of Suez reported a single summer spawning period from June to September (Pearse 1969; Hasan, 1995).

Whether we agreed or disagreed with Pearse's assumption, it is certain that temperature has the prime effect on the spawning period as showed at the current study where during the first period (1992-1993), E. mathaei showed a definite annual reproductive cycle during summer season starts at June and ends at August with maximum gonadal activity at July. On the other hand, an obvious shift at the spawning season was recorded during the second period (2015-2016), they don't exhibit a specific breeding season and showed four spawning periods, the first from October to November, 2015, the second from March to April, 2016 the third from June to August, 2016, and the fourth from October to November, 2016. The shift recorded during the present work may be attributed to the rise in water temperature during the 23 years apart between the two periods of study; this is attributed to the global warming phenomena. The environmental parameters have been suggested to play an important role in regulating the reproduction of E. mathaei. These parameters include temperature (Byrne 1990; Guillou and Michel 1993; King et al. 1994; Vai"tilingon et al. 2005; James et al. 2007), photoperiod (Kelso 1971; Pearse et al. 1986; McClintock andWatts 1990;Walker and Lesser 1998; Shpigel et al. 2004), salinity (Harrington et al. 2007), food availability (Lawrence and Lane 1982; Poorbagher et al. 2010), population density (Bay-Schmith and Pearse, 1987), wave swept area (Muthiga and Jaccarini, 2005) and pH (Pearse and Cameron 1991), from these parameters temperature have the major role in governing E. mathaei reproduction. This was recorded from the current study as well as from other studies (Byrne, 1990; Siikavuopio et al., 2006, 2008)

Gonadal indices and their changes over time have been used as indicators of reproductive cycle for many species of marine animals. They are often called "reproductive efforts" which measure the energy expenditure by individuals on reproduction. The increase in GSI during the period of gonad maturation is mainly due to deposition of large amount of protein and lipids in the developing eggs and spermatozoa. It is therefore reasonable to expect that the weight of the gonad would reflect the accumulation and utilization of these energy reserves (Fauda, 1990; ElSayed, 1992; Hasan, 1995).

The actual manner in which sex ratio is controlled be of little relevance to the phenology of reproduction although more power forces most favor the existence of primary sex ratio close to one. The link with adaptedeness may be more apparent in other aspects of reproduction which include sexual characteristics, age and maturity, season of spawning and feature of egg size and fecundity. However, overall sex ratio( males to females) during the first period (1992-1993) of the current study was $1: 2.5$ in 1992-1993, with a percentage of $20 \%$ males and $80 \%$ females. While in 2015-2016, it recorded an average male to female of 1:2.4 with percentage $35.2 \%$ males and $64.8 \%$ females. The sex ratio was significantly deviated from the expected ratio 1:1 at the two periods, but the deviation was more in 1992-1993 than in 2015- 
2016. However, the ratio is not constant throughout the period of study particularly during the spawning season. Generally, females markedly outnumbered males all the year around particularly during summer and autumn months at the first period (19921993), while at the second period (2015-2016), the number of females still outnumbers males throughout the year but with less deviation from the 1:1 ratio. This ratio was not consistent throughout the year particularly at the end of spawning season which number of females was relatively exceeds the number of males. Generalization about sex ratios at the species level should be made with caution because local variation from ratio of 1:1 may be caused by differential mortality, migration or habitat selection, and restricted nutrition (Warner, 1977; Cobb and Caddy, 1989).

Based on the agreement between gonad indices and gametogenesis E. mathaei have a definite annual reproductive cycle at summer during the period 1992-1993. On the other hand, the same species showed unusual spawning pattern at the period 2015-2016 and it recorded a lengthy spawning season with repeating spawning throughout the year. The differences in the mean gonadal index between the two periods may reflect either difference in individual growth of the gonads or in the degree of synchronization of gonadal development in the population (Byrne 1990). If the individuals in the population are synchronized, that if they all grow and ripen together, changes in the mean gonadal index will reflect individual gonadal growth and not all the maturity stages will be represented at all seasons as the case in the first period of study (1992-1993). If the gonads grow and mature at different times, all maturity stages will be represented in the population as the case recorded during the second period (2015-2016) of the current study. The present study indicates that individuals of $E$. mathae $i$ were asynchronized in their reproductive cycle during the period from 2015 to 2016 since individuals were in different stages of gametogenic development. Hence the population appeared spawn at all seasons. Characteristics of gametogenesis in E. mathaei are similar to most echinoids (Walker et al. 2007). In the first stage, there is nutrient accumulation with gonad increase in size. Following nutritive build up, gametogenic cells began to grow and mature along the ovarian wall as the nutritive cells decrease. The mature oocytes and sperms occupying the entire lumen of the gonads with little nutritive materials remaining. At this time the remaining gametes are either reabsorbed or do not grow until the start of the next reproductive period, nutritive materials again begins to accumulate. Hellal (1986) noticed that medium sized oocytes were not seen in the gonads after spawning. In the present study, this phenomena was observed only during the period from 1992 to 1993, while during the period from 2015 to 2016 such a phenomenon was not observed, where all stages of gametogenesis were found in the gonads throughout the year. This indicated that the ripe individuals occur throughout the year and rarely are all the individuals ripe at any one time, but at least some ripe individuals should almost always be present. The presence of small oocyte with very low proportions in the gonads of E. mathaei during spawning season shows maturing of all oocytes. The relationship between spawning and the length of time eggs held in the gonads is rather complicated. If egg production is continuous and extended over several months, an animal could release egg cautiously with little storage, release eggs in short bursts or release eggs all at once. In the present study, during the period 20152016, individuals of populations of E. mathaei reach ripeness at different times and spawning involving different individuals, must be continuous during the year

As concluded in the current study elevation of temperature due to global warming phenomena affected the reproductive status of Echinometra mathaei at the 
Gulf of Suez as a part of ocean life, this life in the sea as whole was affected. The change of the normal pattern of life will greatly affect the entire ecosystems and environmental stability.

\section{REFERENCES}

Abdelmongy, A. S. and El-Moselhy K. M. (2015). Seasonal Variations of the Physical and Chemical Properties of Seawater at the Northern Red Sea, Egypt. open journal of ocean and coastal sciences issn (Print): 2377- 0007 Issn (Online): 2377-0015. DOI: 10.15764/OCS.2015.01001, 2(1): 1-17.

Abou Zied, M.M. (1991). Biological studies on some bivalves from the Suez Canal. Ph.D. thesis, Zool. Dept., Faculty of Science, Al-Azhar Univ.

Arakaki, Y. and Uehara, T. (1991). Physiological adaptation and reproduction of the four types of Echinometra mathaei. In: Biology of Echinodermata. Yanagisawa, T.; Yasumasu, I.; Oguro, C.; Suzuki, N. and Motokawa, T. (eds). A.A. Balkema, Rotterdam, pp. 105-111.

Alsaffar, A. H. and Lone, K. (2000). Reproductive cycles of Diadema setosum and Echinometra mathaei (Echinoidea: Echinodermata) from Kuwait (Northern Arabian Gulf). Bulletin of Marine Science -Miami- 67(2):845-856

Bay-Schmith, E. and Pearse, J. S. (1987). Effect of fixed daylengths on the photoperiodic regulation of gametogenesis in the sea urchin Strongylocentrotus purpuratus. International J. Invert. Reprod. Development, 11:287-294.

Bronstein, O. and Loya, Y. (2014). Echinoid community structure and rates of herbivory and bioerosion on exposed and sheltered reefs. J. exp. mar. Biol. Ecol., 456: 8-17. https://doi.org/10.1016/j. jembe.2014.03.003

Byrne, Maria. (1990). Annual reproductive cycles of the commercial sea urchin Paracentrotus lividus from an exposed intertidal and a sheltered subtidal habitat on the west coast of Ireland. Mar. Biol., 104: 275-289. https://doi.org/10.1007/BF01313269

Byrne, Maria; Melanie Ho, Paulina S.; Hong, D.; Nguyen, S.; Dworjanyn, A. and Andy, R. D. (2013). Temperature, but not $\mathrm{pH}$, compromises sea urchin fertilization and early development under near-future climate change scenarios. Published 25 February 2009. DOI: 10.1098/rspb.2008.1935

Cobb, J.S. and Caddy, J.F. (1989). The population biology of decapods. In: Marine invertebrate fisheries their assessment and management. Caddy, J.F (ed). :327373.

Cohen-Rengifo, M.; Garcia, E.; Hernandez, C.A. and Hernandez C.J. (2013). Global warming and ocean acidification affect fertilization and early development of the sea urchin Paracentrotus lividus. Cahiers de Biologie Marine, 54(4): 132143.

Dorgham, M.; El-Sherbiny, M. and Hanafi, M. (2012). "Environmental properties of the southern Gulf of Aqaba, Red Sea, Egypt," Mediterranean Marine Science, vol. 13, no. 2, pp. 179-186.

Drummond, A.E., (1995). Reproduction of the sea urchins Echinometra mathaei and Diadema savignyi on the South African coast. Mar. Freshwater Res., 46:751757. https:// doi.org/ 10.1071/ mf9950751

El-Shenawy M.; Farag A. and Zaky, M. (2006). Sanitary and aesthetic quality of Egyptian coastal waters of Aqaba Gulf, Suez Gulf and Red Sea. Egyptian Journal of Aquatic Research, 32:220-234. 
El-Sayed, A.A.M. (1992). Biological studies on some Brachyuran crabs (crustacean) from Suez Canal. Ph.D. thesis Zool. Dept. Faculty of Science, Al-Azhar university.

Fahmy, M. (2003). Water quality in the Red Sea coastal waters (Egypt): Analysis of spatial and temporal variability. Chemistry and Ecology. 19 (1):. 67-77.

Fauda, F.M.A. (1990). Biological and physiological studies on goby fishes from Timsah lake. Ph.D. thesis, Zool. Deprt., Girl Collage, Ain Shams University.

Fujisawa, H. and Shigei, M., (1990). Correlation of embryonic temperatures sensitivity of sea urchins with spawning season. J. Exp. Mar. Biol. Ecol., 136: 123-139. https://doi.org/10.1016/0022-0981(90)90191-e

Giese, A.C. and Pearse, J.S. (1974). Introduction general principles. In: Reproduction of marine inertebrtes (1). Giese, A.C. and Pearse, J.S. (eds), Academic press, New York, pp. 1-49.

Harrington, L.H.; Walker, C.W. and Lesser M.P. (2007). Stereological analysis of nutritive phagocytes and gametogenic cells during the annual reproductive cycle of the green sea urchin, Strongylocentrotus droebachiensis. Invertebrate Biol 126:202-209.

Hasan, M.H. (1995). Ecological and Biological studies on echinoderms from the Gulf of Suez, Red Sea. M.Sc. thesis, faculty of Science, Suez Canal University, $254 \mathrm{pp}$.

Hellal, A. M. (1986). Biological and ecological studies on some echinoderms of the Red Sea. M.Sc. thesis Faculty of Science, Al-Azhar University.

Held, I. M., Winton, M.; Takahashi, K.; Delworth, T.; Zeng, F. R. and Vallis, G. K. (2010). Probing the fast and slow components of global warming by returning abruptly to preindustrial forcing. J. Clim., 23, 2418-2427.

IPCC, (2013). Summary for Policymakers. In: Climate Change 2013: The Physical Science Basis. Contribution of Working Group I to the Fifth Assessment Report of the Intergovernmental Panel on Climate Change [Stocker, T.F., D. Qin, G.-K. Plattner, M. Tignor, S.K. Allen, J. Boschung, A. Nauels, Y. Xia, V. Bex and P.M. Midgley (eds.)]. Cambridge University Press, Cambridge, United Kingdom and New York, NY, USA.

Kelso, D.P., (1971). Morphological variation, reproductive periodicity, gamete compatibility and habitat specialization in two species of the sea urchin Echinometra in Hawaii. Ph.D Thesis, University of Hawaii.

Keshavarz, M.; Kamrani1, E.; Amrollahi, N.;Zamani, H. (2017). Study on the Gonadosomatic Indices of Sea Urchin Echinometra mathaei in Persian Gulf, Iran. Pakistan J. Zool., vol. 49(3), pp 923-933. DOI: http://dx.doi.org/10.17582/journal.pjz/2017.49.3.923.933.

Kobayashi, N. (1969 ). Spawning periodicity of sea urchins at seto. III. Tripenustes gratilla, Echinometra mathaei, Anthocidaris crassipina and Echinostrephus aciculatus. Sci. Engin. Rev. Doshisha. Univ., 9: 254-269.

King, C. K.; Hoegh-Guldberg, O. and Byrne, M. (1994). Reproductive cycle of Centrostephanus rodgersii (Echinoidea), with recommendations for the establishment of a sea urchin fishery in New South Wales. Marine Biology 120: 95-106.

Knutti, R., and Hegerl, G. C. (2008). The equilibrium sensitivity of the Earth's temperature to radiation changes. Nature Geosci., 1, 735-743.

Knutti, R., and Tomassini, L. (2008). Constraints on the transient climate response from observed global temperature and ocean heat uptake. Geophys. Res. Lett., 35, L09701. 
Knutti, R., Krähenmann, S.; Frame, D. and Allen, M. (2008). Comment on "Heat capacity, time constant, and sensitivity of Earth's climate system" by S. E. Schwartz. J. Geophys. Res., 113, D15103.

Koven, C. D.; Riley, W. J. and Stern, A. (2013). Analysis of permafrost thermal dynamics and response to climate change in the CMIP5 Earth system models. J. Clim., 26, 1877-1900.

Lawrence, J.M. and Lane, P. (1982). The utilization of nutrients by postmetamorphic echinoderms. In: Echinoderm nutrition. Jangoux, M. and Lawrence, J.M. (eds), A.A. Balkema, Rotterdam. Pp. 331-372.

Madkour, H. A. (2013). "Impacts of human activities and natural inputs on heavy metal contents of many coral reef environments along the Egyptian Red Sea coast," Arabian Journal of Geosciences, vol. 6, no. 6, pp. 1739-1752, 2013.

McClintock, J.B. and Watts, S.A. (1990). The effects of photoperiod on gametogenesis in the tropical sea urchin Eucidaris tribuloides (Lamarck) (Echinodermata: Echinoidea). Journal of Experimental Marine Biology and Ecology, 139 (3): 175-184.

McClanahan, T.R. and Muthiga, N.A. (2013). Echinometra. In: Sea Urchin: Biology and ecology (ed. J.M. Lawrence) Academic Press, Florida, MA, pp. 337-353. https://doi.org/10.1016/B978-0-12- 396491-5.00023-X.

Mercier, A. and Hamel, J.F. (2009). Endogenous and Exogenous Control of Gametogenesis and Spawning in Echinoderms. Advances in Marine Biology, 55: $1-302$.

Morcos, S.A. (1970). Phsical and chemical oceanography of the Red Sea. Oceanog. Mar. Biol. Ann. Rev., 8: 73-202.

Murintsev, A.M. (1963). The princible Hydrological features of the pacific ocean. U.S. Department of commerce, Washington DC (IPST cat. No. 753). Pp. 417.

Muthiga, N. and Jaccarini, V., (2005). Effects of seasonality and population density on the reproduction of the Indo-Pacific echinoid Echinometra mathaei in Kenyan coral reef lagoons. Mar. Biol., 146: 445- 453. https://doi.org/10.1007/s00227-004-1449-9

Pearse, J.S. (1968). Ptterns of reproductive periodicities in four species of Indopacific echinoderms. Proc. Ind. Acad. Sci., 67:247-279.

Pearse J.S. (1969).Reproductive periodicities of Indo-pacific invertebrates in the Gulf of Suez. II. The echinoid Echinometra mathaei. Bull. Mar. Sci., 19:580613.

Pearse, J.S. (1974). Reproductive patterns of tropical reef animals: three species of sea urchins. Proc. Second Int. Coral Reef Symp. 1: 235-240.

Pearse, J.S. (1983). The Gulf of Suez: signs of stresses on a tropical biota. Bull. Inst. Oceanog. And Fish., ARE, 9:148-159.

Pearse, J.S. and Barksdale, M.J. (1986). Temporal patterns of reproduction by shallow water invertebrates in the Indian Ocean. In: Biology of benthic marine organisms. Thompson, M.F.; Sarojini, R. and Nagabushanam, R. (eds) Oxford and IBH bublishing company, New Delhi, Bombay, Calcutta.

Pearse, J.S. and Phillips, B.F. (1968). Continous reproduction in the Indo-pacific sea urchin, Echinometra mathaei at Rottnest Island, Western Australia. Aust. J. Mar. Freshwat. Res., 19: 161-172.

Pearse, J. S. and Cameron, R. A. (1991). Echinodermata: Echinoidea. In: Giese, A. C.; Pearse, J. S.; Pearse, V. B. ed. Reproduction of marine invertebrates. California, The Boxwood Press. Pp. 513-662. 
Pearse, J.S.; Pearse, V.B. and Davis, K.K. (1986). Photoperiodic regulation of gametogenesis and growth in the sea urchin Strongylocentrotus purpuratus. J. Exp. Zool., 237:107-118

Pecorino, D.; Barker, M.F.; Dworjanyn S.A.; Byrne, M.; Lamare, M.D. (2014). Impacts of near future sea surface $\mathrm{pH}$ and temperature conditions on fertilisation and embryonic development in Centrostephanus rodgersii from northern New Zealand and northern New South Wales, Australia. Mar Biol 161:101-110.

Poorbagher, H.; Lamare, M.D.; Barker, M.F. and Rayment, W. (2010). Relative importance of parental diet versus larval nutrition on development and phenotypic plasticity of Pseudechinus huttoni larvae (Echinodermata: Echinoidea). Marine Biology Research, 6: 302-314.

Por, F.A. (1978). Lessepsian migration. Springer verlage, Berlin.

Sakairi, K.; Yamamoto, M.; Ohtsu, K. and Yoshida, M. (1989) Environmental control of gonadal maturation in laboratory-reared sea urchins, Anthocidaris crassispina and Hemicentrotus pulcherrimus. Zool Sci, 6:721-730

Shpigel M, McBride SC, Marciano S, Lupatsch I (2004). The effect of photoperiod and temperature on the reproduction of European sea urchin Paracentrotus lividus. Aquaculture, 232:343-355

Siikavuopio, S. I., Mortensen, A. and Christiansen, J. S., (2008). Effects of body weight and temperature on feed intake, gonad growth and oxygen consumption in green sea urchin, Strongylocentrotus droebachiensis. Aquaculture, 281: 7782. https://doi.org/10.1016/j.aquaculture.2008.05.033

Siikavuopio, S. I., Christiansen, J. S. and Dale, T., (2006). Effects of temperature and season on gonad growth and feed intake in the green sea urchin (Strongylocentrotus droebachiensis). Aquaculture, 255: 389-394. https://doi.org/10.1016/j. aquaculture.2005.12.021

Stocker, T.F.; Qin, D.; Plattner, G.-K; Alexander, L.V.; Allen, S.K.; Bindoff, N.L.; Bréon, F. M; Church, .J.A.; Cubasch, U.; Emori, S.; Forster, P.; Friedlingstein, N.; Gillett, J.M.; Gregory, D.L.; Hartmann, E.; Jansen, B.; Kirtman, R.; Knutti, K.; Krishna Kumar, P.; Lemke, J.; Marotzke, V.; Masson-Delmotte, G.A.; Meehl, I.I.; Mokhov, S.; Piao, V.; Ramaswamy, D.; Randall, M.; Rhein, M.; Rojas, C.; Sabine, D.; Shindell, L.D.; Talley, D.G.; Vaughan, D.; and Xie, S. P. (2013). Technical Summary. In: Climate Change 2013: The Physical Science Basis. Contribution of Working Group I to the Fifth Assessment Report of the Intergovernmental Panel on Climate Change [Stocker, T.F., D. Qin, G.-K. Plattner, M. Tignor, S.K. Allen, J. Boschung, A. Nauels, Y. Xia, V. Bex and P.M. Midgley (eds.)]. Cambridge University Press, Cambridge, United Kingdom and New York, NY, USA.

Tailing, J.F. (1976). Water characteristics. In: The Nile biology of an ancient river. Rzoska,J. (ed.), the Hague Jeuk Publ.: 357-381.

Vaitilingon D.; Rasolofonirina, R. and Jangoux, M. (2005). Reproductive cycle of edible echinoderms from the southwestern Indian Ocean I. Tripneustes gratilla L. (Echinoidea, Echinodermata). Western Indian Ocean Journal of Marine Science 4:47-60

Walker, C.W. and Lesser, M.P. (1998). Manipulation of food and photoperiod promotes out-of-season gametogenesis in the green sea urchin, Strongylocentrotus droebachiensis: implications for aquaculture. Mar Biol, 132:663-676. 
Walker, C.W.; Unuma, T. and Lesser, M.P. (2007). Gametogenesis and reproduction of sea urchins. In: Lawrence JM (ed) Edible sea urchins: biology and ecology. Elsevier, Amsterdam, pp 11-33.

Wangensteen, O.S; Turon, X.; Casso, M. and Palacin, C. (2013.) The reproductive cycle of the sea urchin Arbacia lixula in northwest Mediterranean: potential influence of temperature and photoperiod. Mar Biol, 160:3157-3168.

Warner, G. F. (1977). The biology of crustacean. ELK Science, London, pp. 202. 